\title{
Study of cavernous underground conduits in Nam La (Northwest Vietnam) by an integrative approach
}

\author{
V. T. Tam • F. De Smedt • O. Batelaan - L. Q. Hung • \\ A. Dassargues
}

\begin{abstract}
This paper presents the result of an investigation of underground conduits, which connect the swallow holes and the resurgence of a blind river in the tropical, highly karstified limestone Nam La catchment in the NW of Vietnam. The Nam La River disappears underground in several swallow holes near the outlet of the catchment. In the rainy season this results in flooding upstream of the sinkholes. A hypothesis is that the Nam La River resurges at a large cavern spring $4.5 \mathrm{~km}$ east of the catchment outlet. A multi-thematic study of the possible connections between the swallow holes and the resurgence was carried out to investigate the geological structure, tectonics, cave structure analysis and discharge time series. The existence of the underground conduits was also tested and proven by tracer experiments. On the basis of a lineament analysis the location of the underground conduits were predicted. A remote sensing derived lineament-length density map was used to track routes from the swallow holes to the resurgence, hav-
\end{abstract}

Received: 6 November 2003 / Accepted: 22 February 2005

Published online: 21 May 2005

(C) Springer-Verlag 2005

V. T. Tam

Research Institute of Geology and Mineral Resources, Ministry of Natural Resources and Environment,

Km 9 Nguyen Trai Street, Thanh Xuan, Hanoi,, Vietnam

e-mail:vttam@pmail.vnn.vn

F. De Smedt · O. Batelaan $(\bowtie) \cdot$ L. Q. Hung

Department of Hydrology and Hydraulic Engineering, Vrije

Universiteit Brussel,

Pleinlaan 2,

1050 Brussels, Belgium

e-mail: batelaan@vub.ac.be

Tel.: +32-2-6293039

Fax: +32-2-6293022

\section{A. Dassargues}

Département Géoressources, Géotechnologies et Matériaux de

Construction (GEOMAC), Université de Liège,

B.52 Sart-Tilman,

4000 Liege, Belgium

\section{A. Dassargues}

Department of Geography-Geology, Hydrogeology and

Engineering Geology,

KU Leuven, Redingenstraat 16 ,

3000 Leuven, Belgium ing the shortest length but highest lineament density. This resulted in a plan-view prediction of underground conduits that matches with the cave and fault development. The functioning of the conduits was further explained by analysing flooding records of a nearby doline, which turns out to act as a temporary storage reservoir mitigating flooding of the catchment outlet area.

Résumé Cet article présente les résultats de l'investigation de conduits souterrains, qui mettent en connexion les pertes et les résurgences d'une rivière souterraine dans le bassin versant de Nam La, dans une région tropicale fortement karstique du NW du Vietnam. La rivière Nam La disparaît dans le sous-sol via plusieurs pertes à proximité de l'exutoire du bassin. Durant la saison des pluies, les pertes se mettent en charge et des inondations apparaissent. Une hypothèse serait que la rivière ressort $4.5 \mathrm{~km}$ à l'Est de l'exutoire du bassin, dans une grande caverne. Une étude multi-thématique visant les connexions possibles entre les pertes et les résurgences a été réalisée. Elle comprend l'étude de la structure géologique, la tectonique, l'analyse de la structure karstique et des chroniques de débits. L'existence des conduits souterrains est également testée et prouvée par des essais de traçages. Sur base de l'analyse des linéaments, la localisation des conduits souterrains est prédite. Grâce à la télédétection et une cartographie de la densité et de la longueur des linéaments, on peut deviner le cheminement de l'eau entre les pertes et la résurgence (via le chemin le plus court et la densité de fracturation la plus importante). Il en résulte une vue en plan prédisant la localisation des conduits, qui correspond par ailleurs avec le développement des cavités et des failles. Le fonctionnement des conduits est ensuite expliqué sur base de l'analyse des chroniques de débits enregistrés à proximité d'une doline, qui joue le rôle d'un réservoir temporaire, mitigeant les inondations à la zone de l'exutoire du bassin-versant.

Resumen Este artículo presenta el resultado de una investigación de conductos subterráneos, los cuales conectan dolinas y la resurgencia de un río ciego en la cuenca tropical Nam La, compuesta por calizas altamente karstificadas, en el noroeste de Vietnam. El Río Nam La desaparece en el subsuelo por medio de varias dolinas cerca de la salida de 
la cuenca. Durante la estación lluviosa esto resulta en inundaciones aguas arriba de las dolinas. Una hipótesis es que el Río Nam La resurge en un manantial de caverna grande a $4.5 \mathrm{~km}$ al oriente de la salida de la cuenca. Se llevó a cabo un estudio multi-temático de las conexiones posibles entre las dolinas y la resurgencia para investigar la estructura geológica, tectónica, análisis estructural de cavernas, y series de tiempo de descarga. Se evalúa y se demuestra también la existencia de conductos subterráneos por medio de experimentos con trazadores. En base a análisis de lineamientos se predice la localización de los conductos subterráneos. Se utiliza un mapa de densidad de longitudes de lineamientos construido a partir de sensores remotos para seguir las rutas de las dolinas a la resurgencia, teniendo longitudes más cortas pero densidad de lineamientos más altas. Esto da por resultado una predicción en vista de planta de conductos subterráneos que se ajustan con el desarrollo de cavernas y fallas. El funcionamiento de los conductos se explica posteriormente mediante el análisis de registro de inundaciones de una dolina cercana la cual actúa como un reservorio de almacenamiento temporal que mitiga inundaciones en el área de salida de la cuenca.

Keywords Vietnam $\cdot$ Karst $\cdot$ Carbonate rocks . Lineament . Tracer test

\section{Introduction}

Two notions are of particular concern regarding karst areas, especially for the closed karstic valleys: (i) surface water and groundwater interact directly through sinkholes and shafts developed in high-relief terrains; (ii) the surface drainage system is blinded and passes through open conduits called swallow holes or may infiltrate through a soil mantle to a dendritic system of enlarged joints, bedding planes and conduits, and later resurges at a distance from the sinkholes. Karst systems in most cases flush very rapidly, i.e. most of what enters the system moves rapidly and completely through the system (Kresic et al. 1992). Depending upon the conveying capacity of the karst system with respect to particular rainfall events, closed valleys can often suffer from flooding or water stagnancy near a swallow hole area. This phenomenon is the most problematic water problem in the study area and was, therefore, one of the motivations for this study.

Karstic carbonate aquifers are extremely heterogeneous with a distribution of permeability that spans many orders of magnitude. A "triple permeability" model is often conceptualised, consisting of the rock matrix, the fracture system and the cavernous conduits. The geological framework, including stratigraphic, lithologic and geotectonic factors, strongly influences the hydrodynamic functioning of a karstic aquifer. Often, conduit systems act as lowhydraulic-resistance drains, so that the flow field in the surrounding matrix and fracture system is directed toward the conduit rather than toward groundwater discharge zones on the surface (White 1969; Smart and Hobbs 1986; Ford and Williams 1989; Palmer 1991). Therefore, knowledge of the pattern and distribution of cavern conduits is necessary to obtain a realistic insight of the groundwater flow direction in karstic terrains.

Methods to investigate the hydrodynamic functioning of a karstic aquifer have been developed and utilized by karst hydrologists. These methods can be classified into four major groups: (i) methods based on time series analysis to infer the hydrologic importance of a karstic system at catchment scale (Mangin 1984; Padilla and Pulido-Bosch 1995; Larocque et al. 1998) or of a particular cavernous conduit under investigation (Felton and Currens 1994; Estrela and Sahuquillo 1997; Jian et al. 1998; Bonacci 2001); (ii) methods based on numerical groundwater simulation to estimate the karstic aquifer parameters (Király et al. 1995; Eisenlohr et al. 1997; Larocque et al. 1999); (iii) methods based on remote-sensing data analysis, e.g. lineament analysis, to infer groundwater collectors (Mabee et al. 1994; Sander et al. 1997; Edet et al. 1998; Magowe and Carr 1999; Lachassagne et al. 2001), and (iv) methods based on the integrative analysis of cave surveying and geostructural data to delineate cave origin, distribution pattern, and hydrogeological functioning of cavernous conduits under study (Ford and Ewers 1978; Palmer 1991; Dreybrodt 1992; Sasowsky 1999). Due to high heterogeneity and complexity of the karst environment, and usually the lack of relevant data, none of these methods can individually be considered as a robust tool for karst hydrologic studies. An integrative approach combining several methods can, however, result in a better understanding of karst hydrology.

Tracer experiments have been widely used in the practice of karst hydrology to ascertain the connection between sinkhole(s) and resurgence(s), via underground cavern conduits. After a successful test, often attempts are made to predict the flow path between sinkhole and resurgence based on cave development, relief, geostructure (rock bedding and dipp), distribution of faults and shear zones. Certain practical rules are commonly employed in such a predictive approach, that is (i) bedding-parting planes, joints, and faults all serve as important links in large cave systems; bedding planes appear to be more significant in thin bedded limestones while joints and fractures seem to be more important in shallow and thick bedded (massive) limestones (Knez 1997; Ford 1999); (ii) groundwater tends to concentrate in the rock discontinuities (fractures), and moves through intersected clusters of highly fractured rocks downgradient to the resurgence point. These rules and other criteria although often unproven yield more insight than a long-straight line with arrow headed towards the resurgence point as occasionally seen in publications.

The main objective of this study was to contribute to the karst hydrogeology of the closed Nam La karst catchment in NW Vietnam and more specificly to the functioning of underground conduits, which connect swallow holes and resurgence. Integrative analyses were made on the basis of streamflow hydrographs, cave mapping, geostructural and tectonic data, each contributing to the understanding of possible underground connections and conduits. The results were compared to identify the most likely connections, which were verified by tracer experiments. Efforts 
were made to combine knowledge on cave development, fault distribution, and density of lineaments extracted from satellite images to predict the locations of the underground conduits connecting the swallow holes and the resurgence. The functioning of the conduit system was further investigated by a water balance calculation, which revealed that during extensive rainy periods when the streamflow is very high, the conduit water is temporarily stored in nearby dolines.

\section{Study area}

The Nam La catchment is located on a high mountain plateau at an elevation of 560-1,700 m a.s.l. and encompasses an area of $460 \mathrm{~km}^{2}$ (Fig. 1a). The catchment is characterized by a humid subtropical climate with extensive summer rainfall; the mean annual temperature and precipitation is respectively $21.1^{\circ} \mathrm{C}$ and $1,450 \mathrm{~mm}$. The catchment can be divided into two regions: (i) the northern part, shown in Fig. 1b, occupies one third of the catchment area and is characterized by Carboniferous-Permian to Triassic limestones, which are strongly folded, and (ii) the southern part consisting of Proterozoic to Ordovician terrigeneous rocks, which are weakly metamorphosed, strongly sheared and deformed, and wavy micro-folded. Due to the activation of the Chieng Den and the Da River fault (Fig. 1c), the limestone in the northern part, especially those of Middle Triassic age, are relatively uplifted with respect to the older terrigeneous rocks in the southern part. The structural axes are NW-SE-trending, forming local anticlines and synclines. In addition, the karst formations are dissected by NW-SE, SW-NE, sub-latitudinal and sub-parallel-trending faults. Along these faults limestones are fractured and precipitation runoff is concentrated resulting in extensive development of karst features. The humid tropical climate with high rainfall and intense biochemical processes leads to the acidification of the infiltrating water and favours high rates of karst denudation and cave formation. The carbonate rocks are highly fractured and karstified, resulting in high groundwater storage in the area. Solution conduits and underground passages are abundant, but only act as groundwater collectors and conveyers (Tam et al. 2001). Available hydrogeological data do not show the existence of a karstic groundwater table above the elevation of the Nam La valley. Therefore, above this level the karstic groundwater was estimated to reside as perched volumes along the fractures and shear zones, where the karstic cavern conduits develop. The groundwater tends to flow locally towards the nearest conduits that eventually drain the karstic groundwater to discharge points, e.g. the Hang Doi resurgence. The actual karstic groundwater table likely exists only above the level of Hang Doi resurgence. As the conduits commonly develop in accordance with the structural axes, the karstic groundwater movement was conceptualized to be in a NWSE direction.

The only surface drainage system in the catchment is the Nam La River, which disappears underground in several swallow holes in a blind valley near the Cao Pha Pass.
Along the river course there are a number of swallow holes and resurgences through which the surface water and karst groundwater interaction occurs. The swallow holes near the Cao Pha Pass, which constitute the outlet of the Nam La catchment, resulted from regional faulting (Hop 1996). These swallow holes are grouped by location and by their drainage capacity as follows: Ban Ai, Bom Bay and Cao Pha, at an elevation of respectively 572, 546 and $560 \mathrm{~m}$ a.s.1.. The Bom Bay swallow hole is located in a depression that is $16 \mathrm{~m}$ lower than the Nam La River. The depression is droughty during the dry season but it turns into a lake in the rainy season. Most of the swallow holes are partly blocked by sediments, boulders and straw. Consequently, inundations after rainstorms often occur in the Nam La River valley upstream of the swallow holes. The largest flooding calamity was in 1991 when the inundated area extended from the swallow holes up to Son La Town, a city with 60,000 residents located $7 \mathrm{~km}$ upstream of the swallow holes. This flood resulted in the loss of 21 human lives, several thousand head of cattle, and infrastructure damage of half a million dollars.

A huge spring in the Hang Doi cave, at an elevation of $136 \mathrm{~m}$ a.s.l. and located $4.5 \mathrm{~km}$ eastwards of the Cao Pha swallow holes, is hypothesized by local residents as the resurgence of the swallow holes (Fig. 2). The only evidence to support this hypothesis is that no other resurgence is found within a radius of $10 \mathrm{~km}$ around the swallow holes. So far, there has been no scientific investigation on the hypothesized connection and karst system between the swallow holes and the resurgence.

\section{Streamflow cross-correlation and cross-spectrum analysis}

Time series analysis, as developed by Jenkins and Watts (1968), has been applied in hydrology by Yevjevich (1972), Spolia and Chander (1973), Long and Derickson (1999) and others. These works have been oriented essentially towards forecasting, extrapolation of data, and estimation of parameters of stochastic models. Methods for the description and the functioning of karstic aquifers appear in Mangin (1984), Padilla and Pulido-Bosch (1995) and Larocque et al. (1998). These works are based on the theory of linear systems to transform an input series into an output series. Hence, hydrologic parameters are lumped into the derived impulse response function, which is then used to interpret the functioning of the system under consideration, e.g. system memory and response time distribution. Commonly the input series of such a model is precipitation, while the output series is often streamflow at the catchment outlet. The main tools of time series analyses are the cross-correlation function (CCF) and the cross-amplitude function (CAF), the mathematical derivation of these functions is given in the Appendix.

In order to detect possible connections between the swallow holes and the resurgence, a cross-correlation and crossspectral analysis were performed in which the total streamflow before the swallow holes was taken as input series and 
a

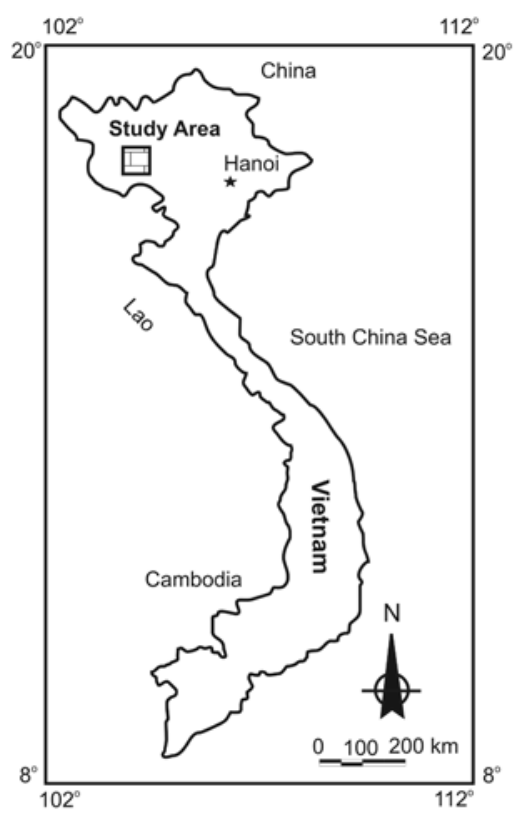

b

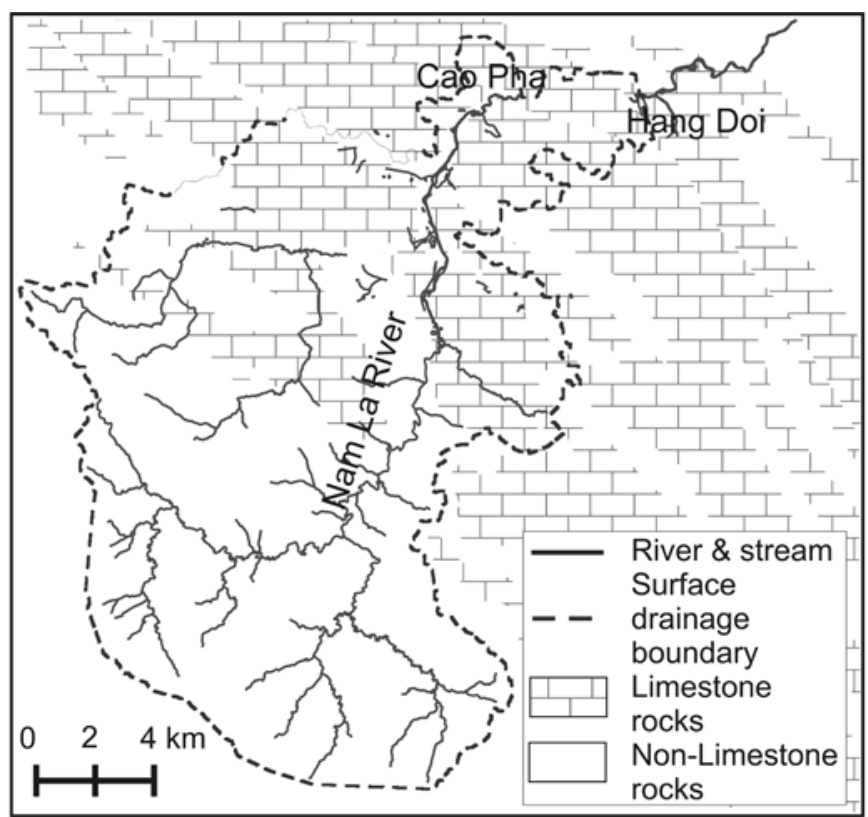

c

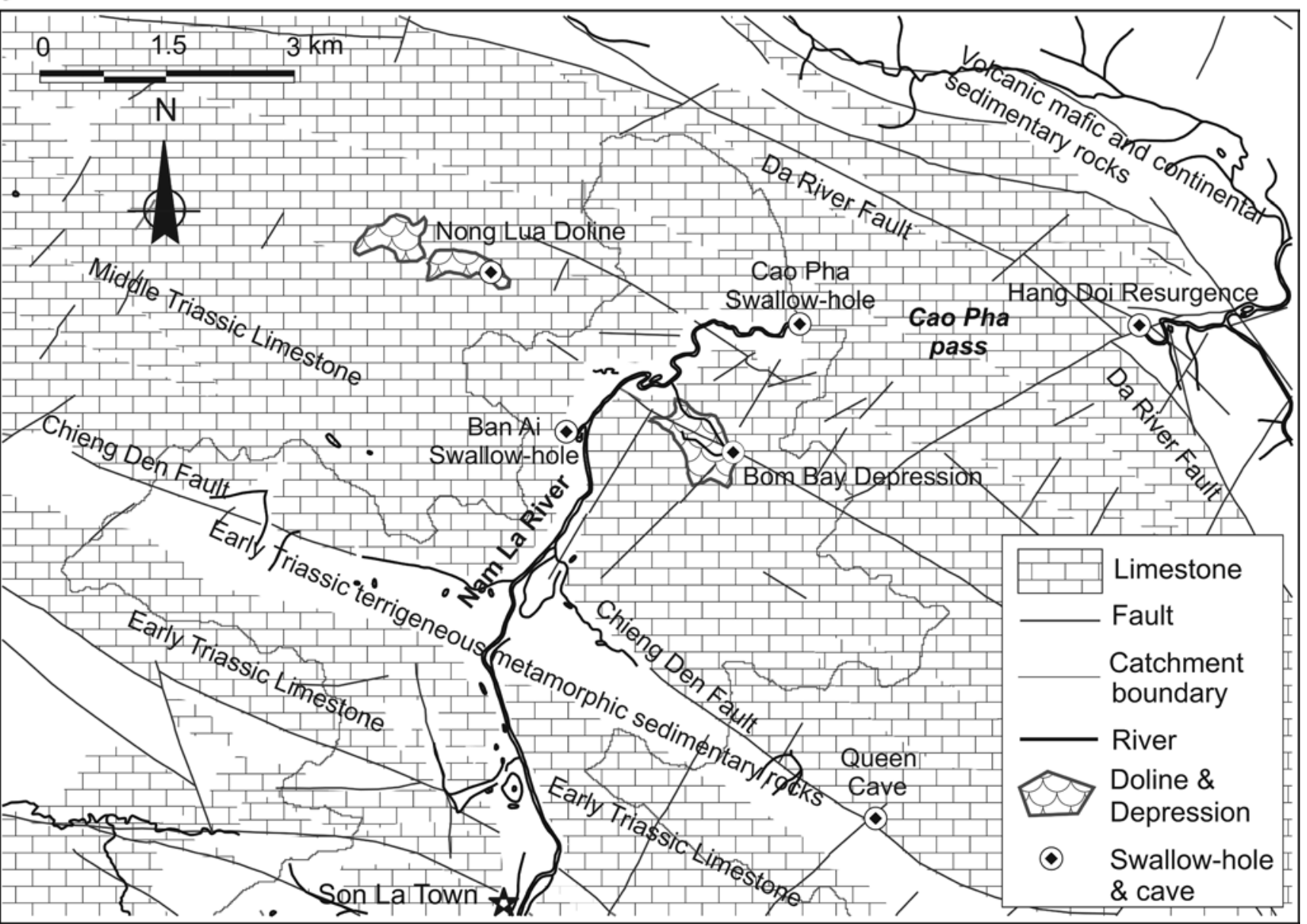

Fig. 1 Location of study area (a), Nam La catchment (b), and schematised geological map of the downstream part of Nam La Cao Pha pass area $(\mathbf{c})$ 


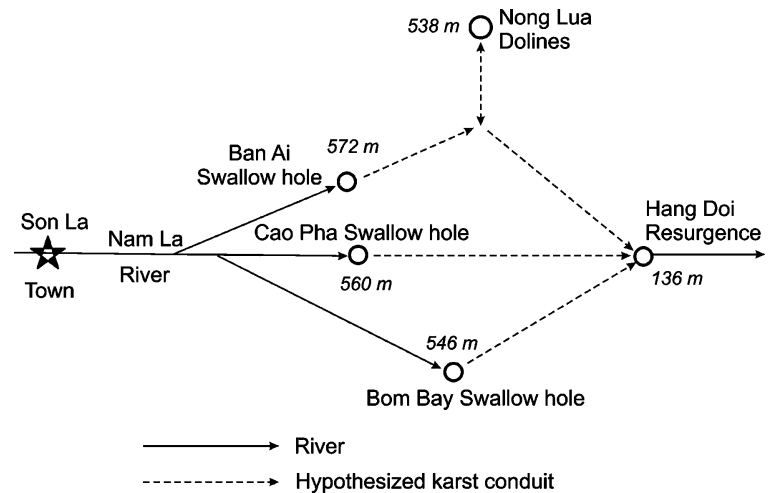

Fig. 2 Schematisation of the Nam La swallow holes and the hypothesized connection to the resurgence, showing the elevation of the swallow holes and resurgence

the discharge of the resurgence as output series (Fig. 3). The data for the analysis was an hourly streamflow hydrograph for the period April 1, 2000 till October 8, 2001 (Fig. 3). Two automatic water level loggers recorded the data, one capturing the total discharge upstream of the swallow holes and the other the discharge of the resurgence. The data series were smoothed by a Tukey filter (Jenkins and Watts 1968) to overcome bias in the determination of the CCF.

The resulting CCF, shown in Fig. 4, diminished slowly with increasing time lag, and reached a zero value at a time lag of 63 days, implying that the duration of the impulse response of the system was quite long. It was therefore concluded that the river discharge, which disappears underground in the swallow holes can have an effect during a period of 63 days on the resurgence outflow. The maximum CCF of 0.92 at a time lag of $13.6 \mathrm{~h}$ implies that (i) there was a strong correlation between the discharge at the swallow holes and the resurgence and (ii) the most visible effect of an input event on the outflow of the system should be observed after $13.6 \mathrm{~h}$. The fact that there was only one peak (for time lag $>0$ ) for the function was an indication that no other flow components significantly influenced the system.

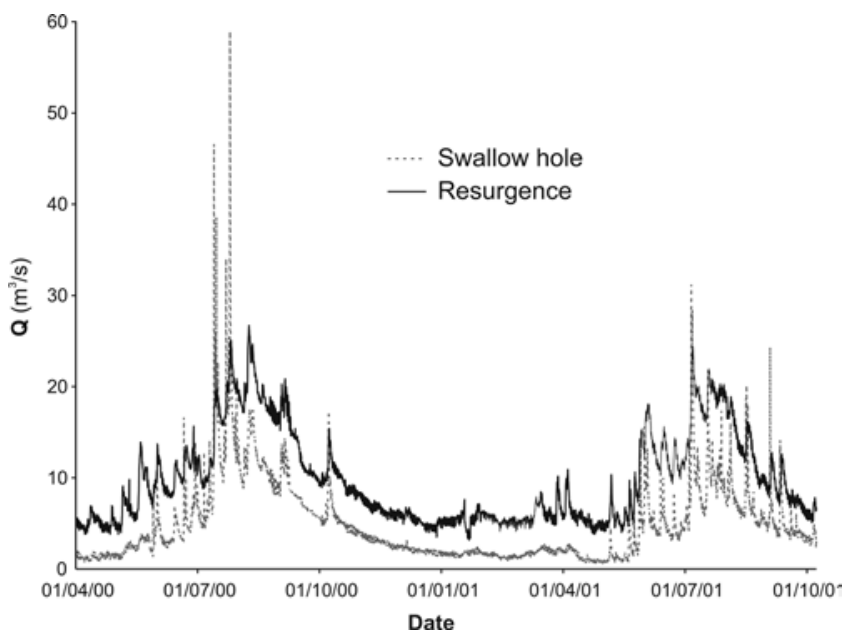

Fig. 3 Streamflow hydrographs of the Nam La swallow holes and the resurgence
The influence can also be visualized in the cross-spectral analysis by the CAF. The low frequency components of the streamflow series provide an appropriate metaphor for smooth changes, e.g. baseflow, while the high frequency components can be associated with abrupt changes, as surface runoff. The cross-amplitude can be interpreted as a measure of covariance between the respective frequency components in the two series. Thus, the spectral analysis of the input and output streamflow series provided information on the functioning of the karst system under investigation. The resulting CAF is given in Fig. 5 and clearly shows that the low frequency $(<0.025)$ components in the input and output series strongly co-vary. It can also be observed that the value of the CAF decreases slowly and reaches practically a zero value for frequencies of more than 0.33 . This indicates that the low-flow (low frequency) components of the input series have a marked response in the output series, while the rapidly changing flow components (high frequency), such as the streamflow peaks during extensive rainy periods, are strongly filtered and attenuated by the underground system. It was therefore hypothesized that floods during extensive rainy periods are dampened by a significant internal storage of the underground conduit system, fractures and fissures or by ponding in certain dolines. This later hypothesis is also supported by a number of facts, which are presented hereafter. Since the input series was the total river discharge before it was swallowed by the swallow holes, it was very hard to make conclusions on the connections of the individual swallow holes and the resurgence, but at least one such connection must exist.

\section{Surface storage ponding of streamflow in dolines and depressions}

A number of discharge monitoring campaigns along the Nam La River were carried out. These show that approximately $50 \%$ of the river discharge disappeared in the Ban Ai swallow hole, $15 \%$ in the Bom Bay swallow hole and $12 \%$ in the Cao Pha swallow hole, while the rest was lost in the river section between Ban Ai and Cao Pha. It is noted that the total inflow of all swallow holes is smaller than the outflow of the resurgence, except at some moments of peak discharge, when the inflow exceeds the outflow (Fig. 3). It was also noticed that the peaks of the resurgence appeared to be constrained to a maximum of about $25 \mathrm{~m}^{3} / \mathrm{s}$. These observations suggest that during periods of high discharge the river water could pond in a surface storage, for instance in nearby dolines, or internally, be stored in an underground reservoir before resurging at the Hang Doi cave.

Two nearby dolines, situated in the Nong Lua village, approximately $2.5 \mathrm{~km} \mathrm{NW}$ of the Ban Ai swallow holes (Fig. 1c), are located at an elevation $34 \mathrm{~m}$ below the level of the Ban Ai swallow holes. A number of caves are found at the bottom of these dolines with entrances, which are partly or fully blocked by rocks, soil debris and tree branches. Dur- 
Fig. 4 Cross-correlation function between the streamflow of the Nam La swallow holes and the Hang Doi resurgence

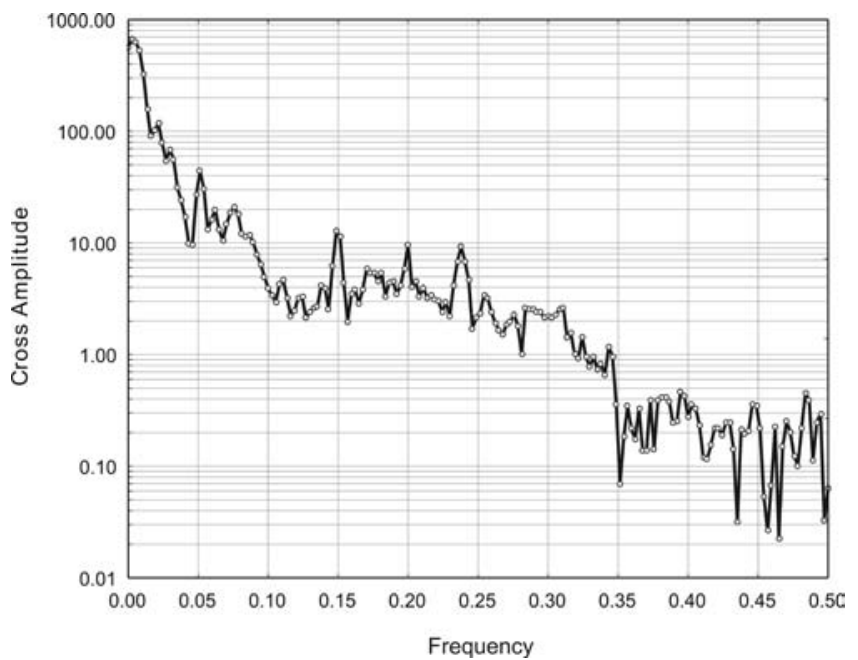

Fig. 5 Cross-amplitude function between the streamflow of the Nam La swallow holes and the Hang Doi resurgence

ing extensive rainy periods, groundwater emerges above the cave entrance and ponds in the dolines for a few days. The time when the groundwater starts to emerge in the dolines was observed to coincide with peak discharges in the Hang Doi resurgence. Ponding in the dolines also occured when the total inflow of the swallow holes was larger than $25 \mathrm{~m}^{3} / \mathrm{s}$ and exceeded the outflow at the resurgence at the Hang Doi cave. It was therefore concluded that the water ponding in the Nong Lua dolines resulted from the streamflow, which disappeared in the Ban Ai swallow hole.

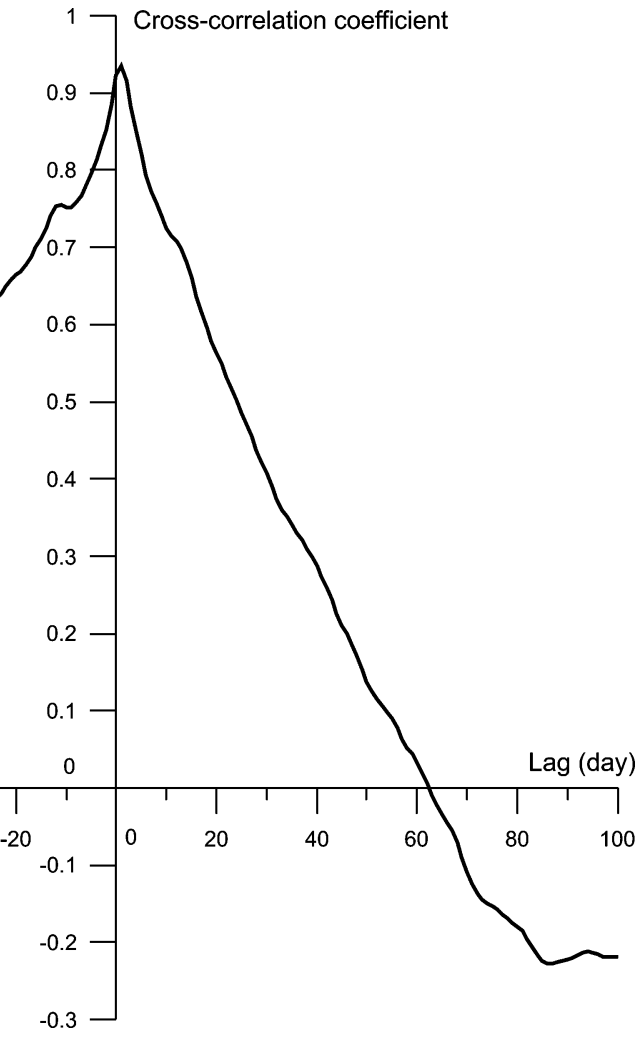

In order to verify the above finding and to find out how the damping of the high floods is related to the ponding in the Nong Lua dolines, the difference of the total inflow and outflow during the period 12-15 July 2000, caused by a total rainfall of $80 \mathrm{~mm}$, was determined to be about $1.4 \times 10^{6} \mathrm{~m}^{3}$ (Fig. 6). A digital elevation model (DEM) with a spatial resolution of $20 \mathrm{~m}$ was developed for the area on the basis of the topographic map of scale 1:50,000 (Turcotte et al. 2001). The volume of excess water was determined with a geographic information system (GIS) fill procedure redistributed over the DEM of the dolines and the Bom Bay depression. In this procedure three constraints were used. The first constraint defined that the minimum water height in the Bom Bay depression was $2 \mathrm{~m}$. This takes into account the field observation that during high discharge periods, $2 \mathrm{~m}$ of water was ponding in the depression but no groundwater rose in the dolines. Since the Bom Bay depression is downstream of the Ban Ai swallow hole, the second constraint is that the maximum water level in Bom Bay was $1 \mathrm{~m}$ below the maximum water level of the Ban Ai swallow hole (Fig. 2). This accounts for the estimated stream head loss from Ban Ai to Bom Bay. The third constraint is that the maximum elevation of the water in the dolines was $2 \mathrm{~m}$ lower than that of the Bom Bay depression. This accounts for the estimated minimum differential head between the water level in the depression and that in the dolines. These conditions also warrant that the minimum differential head between the stream water level in the Ban Ai swallow hole and the highest level of the water in the dolines was at least $3 \mathrm{~m}$, which is regarded as a minimum head loss for the river water to flow through 
Fig. 6 Scheme of calculated excess of discharge at the swallow hole compared to the discharge at the resurgence and distribution of this volume over the Bom Bay and Nong Lua depressions

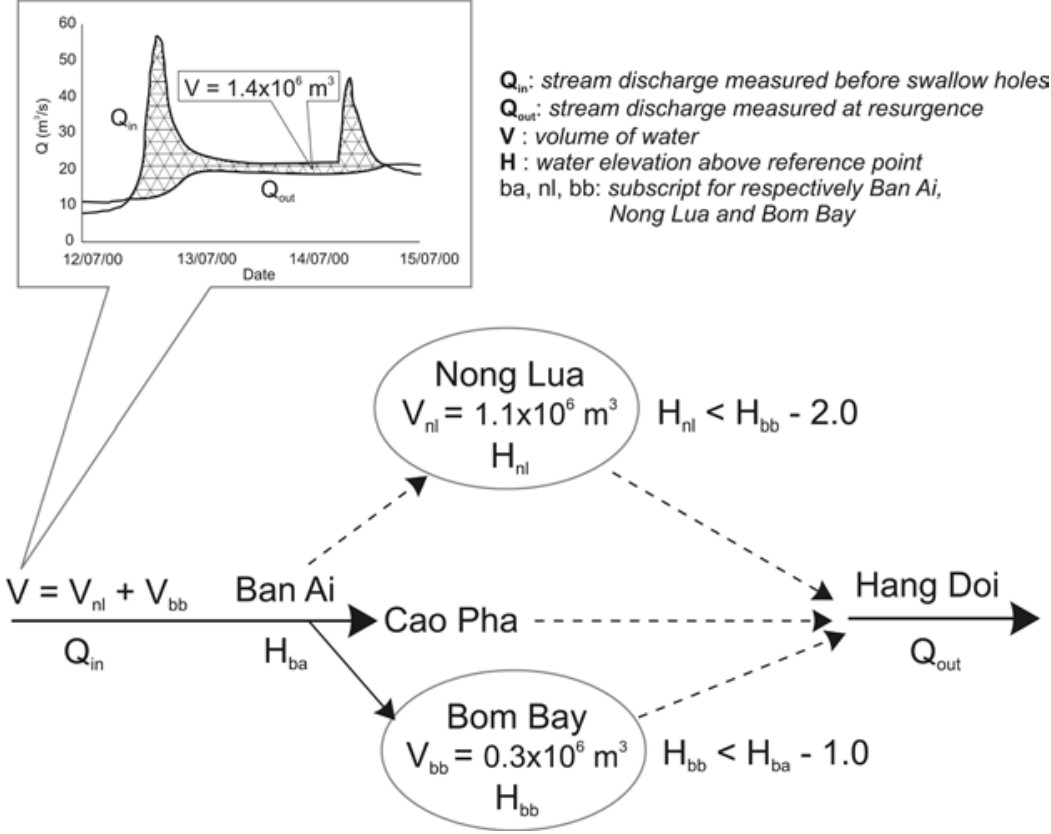

the underground conduit from the Ban Ai swallow hole to the Nong Lua dolines. Applying the fill procedure shows that during the period of interest $0.3 \times 10^{6} \mathrm{~m}^{3}$ were stored in the Bom Bay depression and $1.1 \times 10^{6} \mathrm{~m}^{3}$ in the Nong Lua doline, the latter being equivalent to a water height of about $13 \mathrm{~m}$. This was approximately equal to the flooding traces left on the rock walls in the dolines. The estimated maximum water ponding volume thus showed that the dolines play an important role in flood mitigation of the study area.

\section{Cave development and geostructural analysis}

A moderate to strong karstified limestone landscape characterizes the study region. Many favourable conditions, including geotectonic and neotectonic activities and a humid subtropical climate, facilitate the extensive karstification in the area. Since 1993, a number of caving expeditions have been carried out, primarily focusing on active cavern conduits in the study area. A GIS database has been set up (Dinh 2001), consisting of cave morphology, elevation and location of the explored cavernous passages, development orientation, and groundwater flow direction observed inside the caves. In addition, geostructural data, e.g. the host rock's bedding and dipp, fault location, and topographical information of the ground surface have also been incorporated in the database. This database facilitated a systematic analysis of the cave development in the study area and revealed that the cavern conduits range from a few hundred meters to a few kilometres in length. Their entrance is, in most cases, the end of a surface watercourse in a blind valley or in a depression. Their exit is generally a resurgence located at an elevation more or less equal to that of the surface watercourse, where the karst groundwater discharges. The development of the caves is mostly oriented in two directions, NW-SE and SW-NE, which coincide with the direction of faults and shear zones existing in the study area (Hop 1996; November 1999). The NW-SE direction coincides with the strike of the rock bedding and is the dominant direction of the cave development in the recharge area of the karstic aquifer, while near the Hang Doi resurgence the SW-NE direction is dominant. In the recharge area, a large number of seasonally active (water flowing only during the rainy season) solution passages are present. Most of these developed nearly parallel to the NW-SE strike direction. The cavernous passages tend to be shallow and developed horizontally in the recharge area and at those locations where the rocks are thinly bedded. The closer to the discharge area, the deeper the cavernous passages are in reference to the ground surface. The number of caves is highest in the recharge area and decreases significantly towards the resurgence point. Caves are occasionally composed of multi-segments, starting from the entrance in a karst depression and stepping down by a sequence of sub-horizontal and sub-vertical segments until attaining the point of resurgence. The vertical segments, consisting of shafts up to $100 \mathrm{~m}$ in depth, often coincide with the intersection of two fault systems. Sometimes the lower passage follows a new direction, and is re-oriented over an angle of $90^{\circ}$ or more.

It is further shown that the groundwater mainly resides in fractures and fissures. The cavern conduits, although abundant in the region, have minor groundwater storage and act as collectors and conveyers to drain the groundwater to the discharge point (Tam et al. 2001). The above findings imply that the groundwater system behaves as an unconfined karstic aquifer, where part of the recharge locally occurs through swallow holes or shafts in high relief depressions. In addition, the broad dendritic or branchwork pattern of caves collects water from the karstic aquifer's recharge area and leads the flow toward the discharge point, 
Fig. 7 Development pattern of Queen Cave in relation to fault occurrence, (a) Vertical profile, (b) Plan view (adapted with permission of SPEKUL, Speleoclub of the K.U.Leuven)

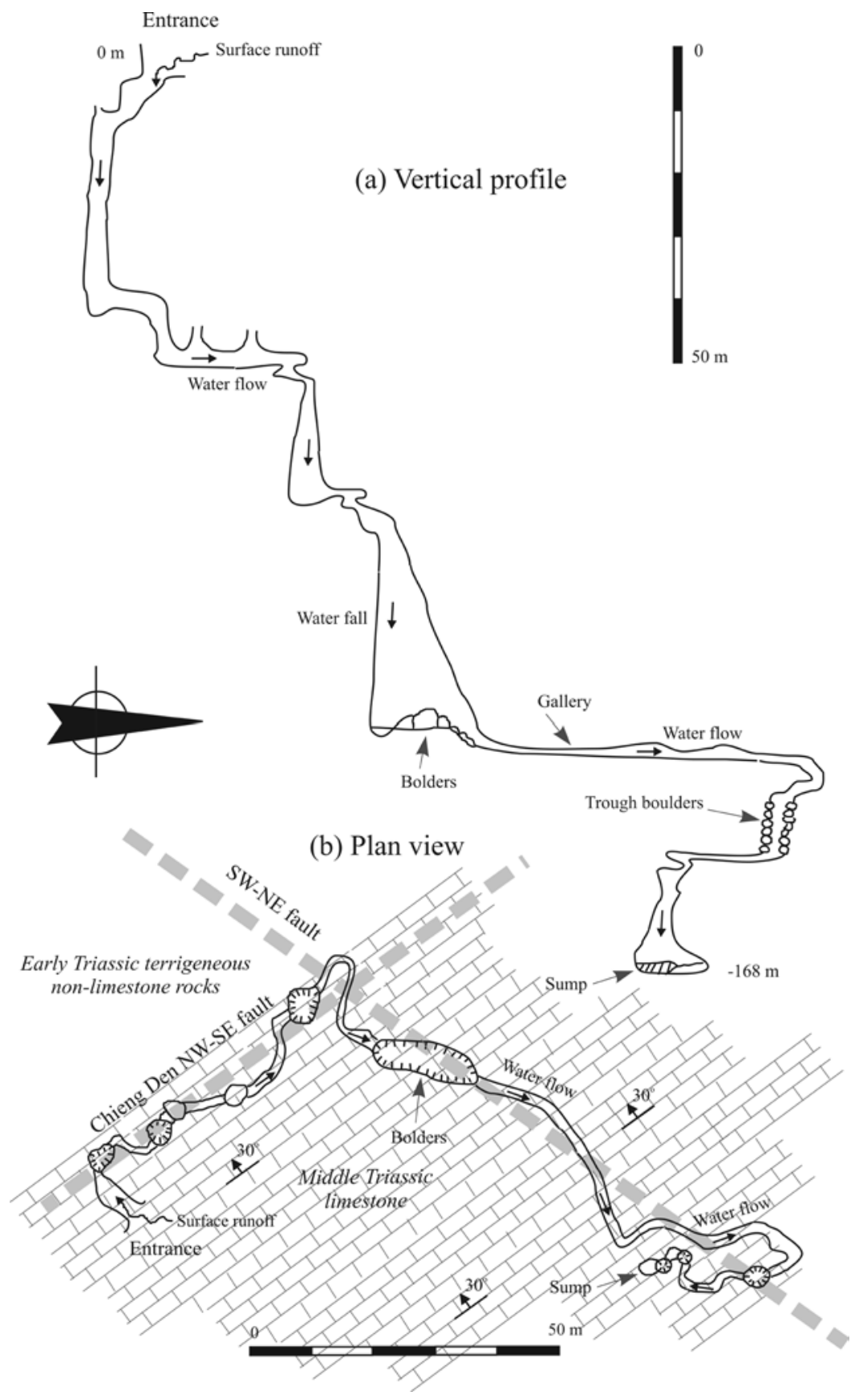

the Hang Doi resurgence. Various examples are found in the cave database, which are compatible with cave genesis concepts addressed in the literature (Davis 1930; Ford and Ewers 1978; Palmer 1991; Dreybrodt 1992; Sasowsky 1999).

According to Ford (1999), different levels of a cave system can be interpreted as the response to changes in the elevation of the springs, especially the lowering of spring elevation as a consequence of erosional base level lowering around the margins of the karst. In the study area, the interpretation is similar but also relates to the faulting activities. A typical example is the development of the Queen cave profile (Fig. 7).
This cave is located in the intersection zone of two faults, the Chieng Den fault extending NW-SE and a smaller fault extending NE-SW. The Chieng Den fault is also a tectonic and stratigraphic boundary, which isolates the older, almost impermeable, terrigenous metamorphic sedimentary rocks in the SW (Fig. 1c) from the younger carbonate rocks in the NE (Hop 1996). Both rocks are sharply dipping SW, and the limestone is uplifted, starting from the Early Pleistocene, with respect to the metamorphic sedimentary rocks. In contrast, it was shown that the northeastern flank of the Da River Fault subsided in comparison with the southwestern flank (Tri and Ngoc 1986). Also during Early Pleistocene, a sudden change from a dry and cold to a tropical hot and 
Fig. 8 Plan view of cave development and groundwater flow direction in the downstream part of the Nam La catchment

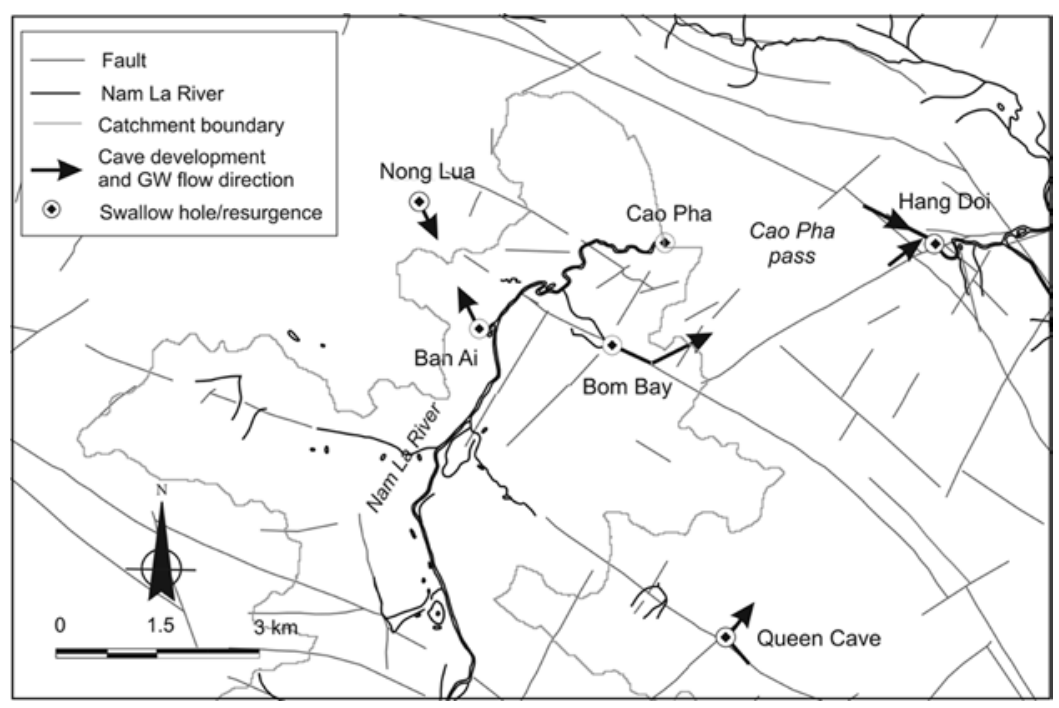

humid climate favoured the early cave development. The Queen Cave was likely initially oriented towards the NW to the local erosional base level, i.e. the Nam La River. But the uplifting of the Middle Triassic Limestone massive and the lowering elevation of the Hang Doi Resurgence consequently led to the creation of the vertical cavern development in the Queen cave. The later formation of the younger SW-NE fault leads to a preferential flow path for the groundwater and therefore a re-orientation of the cave direction from NW-SE to NE-SW. In case of the Queen Cave, the two fault systems obviously drove the cave development and explain why the beginning and end of a cavern conduit can link surface watercourses located at different topographic levels, as in the study area.

The flow between the swallow hole of Ban $\mathrm{Ai}$ and the resurgence at Hang Doi is conceptualised to occur via the Nong Lua cave (Fig. 8). The streamflow disappears in the Ban Ai swallow hole at $572 \mathrm{~m}$ a.s.l. and steps down, along a path of about $2.5 \mathrm{~km}$ length, to the Nong Lua inflow conduit, which is located at $459 \mathrm{~m}$ a.s.l., i.e. $79 \mathrm{~m}$ below the bottom of the doline. Consequently, it drops down along the cavern shaft to the main outflow conduit at $431 \mathrm{~m}$ a.s.l., i.e. $107 \mathrm{~m}$ below the bottom of the doline (Fig. 9). The outflow conduit is thought to lead to the main resurgence at Hang Doi. The conveying capacity of the Nong Lua main outflow conduit is likely limited to about the maximum measured discharge of $25 \mathrm{~m}^{3} / \mathrm{s}$, due to the more or less constant head difference between the swallow hole and the resurgence and the high internal storage. Whenever the inflow exceeds this conveying capacity, the groundwater rises in the shaft and emerges above the cave entrance, resulting in the flooding of the Nong Lua doline.

\section{Validation of underground conduits by tracer experiments}

To verify the existence of the underground conduits two tracer experiments were carried out. The first tracer test was executed at the end of the rainy season of 2001 with
$1.7 \mathrm{~kg}$ of Sulforhodamine B injected in the Bom Bay swallow hole; the second tracer test was executed at the end of the rainy season of 2002 with $2.0 \mathrm{~kg}$ of Uranine injected in the Cao Pha swallow hole. For both tracer tests samples were taken during four days at the Hang Doi resurgence. During the test period, the mean discharge at Bom Bay, Cao Pha and Hang Doi was respectively $0.58 \mathrm{~m}^{3} / \mathrm{s}, 0.62 \mathrm{~m}^{3} / \mathrm{s}$, and $6.28 \mathrm{~m}^{3} / \mathrm{s}$. A Quantech Digital Filter Fluorometer FM109510-33 was used to detect the presence of dyes in the outflow samples. The earliest detected arrival of Uranine was $19 \mathrm{~h}$, and of Sulforhodamine B $20.5 \mathrm{~h}$ after the dyes were injected. However, the concentration of the dyes in the samples was so low that a real break-through curve was hardly detectable. The recovery rate of the injected Uranine was about 35\%, and for Sulforhodamine B only $28 \%$. On the basis of these tracer tests it was proven that underground conduits exists, which connect the Cao Pha and Bom Bay swallow holes to the Hang Doi resurgence. It was also concluded that the underground conduit system has a huge storage, which results in large dilution and mixing. Compared to the results of the cross-correlation and cross-spectral analysis (Figs. 4 and 5) it follows that the mass transfer through the system is much slower than the dynamic response.

\section{Lineament density—based plan-view of predicted underground rivers}

Within the karst aquifer, water moves through interconnected fractures and fissures having widths that range from micrometers to meters. Almost all of the groundwater eventually flows through conduits to a discharge point at a spring. Therefore, understanding the geostructural settings of the region plays a significant role in determining the hydrodynamic properties of the karst aquifer. For decades, many attempts have been made to identify the variety of geologic settings and their controlling influence on branchwork cave development (White 1969, 1999; Ford 1999; 


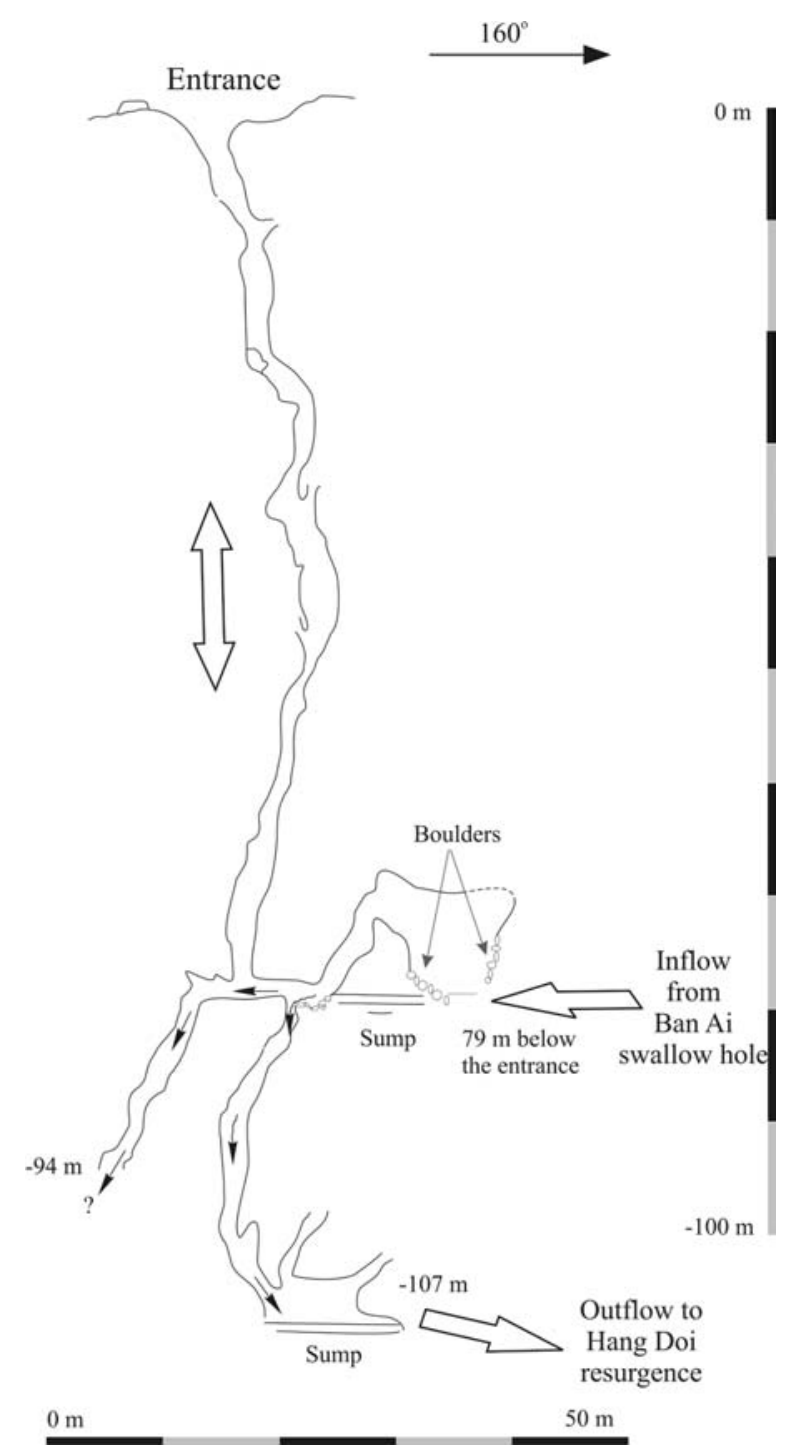

Fig. 9 Vertical profile of Nong Lua Cave. The groundwater enters the cave at a depth of $79 \mathrm{~m}$ below the entrance, flows out at a depth of $107 \mathrm{~m}$, and rises up to the Nong Lua depression during high flow periods (adapted with permission of SPEKUL, Speleoclub of the K.U.Leuven)

Kastning 1999; Palmer 1991; Sasowsky 1999). Although debates on this issue have not ended, widely recognized facts are: (i) cavernous conduits tend to be oriented along the structural strike, especially in regions of strongly folded rocks; (ii) bedding-plane partings provide favourable conditions of two-dimensional flow for cave development, particularly in regions with little folding and nearly flat-lying rocks; (iii) down gradient following the bedrock dip is a preferential development direction for vadose caves; and (iv) faults and their accompanied fractured zones can act as paths of high permeability and concentrated groundwater flow. Consequently, where faults are present, most cave passages will follow them, or at least will follow secondary fractures parallel to them.

In the study area the development of caves is also closely controlled by the geologic structure and tectonic activi- ties. However, the influence of geologic structures on cave development is variable so that it is not possible to provide a set of simple rules to determine the influence of faults and fractures on cave development. Studies on the lineament-fault-cave development relationship in the study area (Hung 2001; Dinh 2001) indicated that: (i) faults are systematically aligned along the areas where the lineament density is high; (ii) most of the caves are found in high-density lineament-fault areas; and (iii) caves often develop along the extended fractured zones that accompany fault systems. Thus, the high density of lineaments and faults can be an indication of the existence of underground conduits.

In this study, an attempt was made to outline a plan-view of the underground conduits between the swallow holes and the resurgence on the basis of lineament density analysis. This work assumes that fractures and fissures of rocks, regardless of lithology, result mainly from geotectonic activities; i.e. faulting is the primary driving force of the rock fracturing and fissuring, and the more faults in an area of interest, the more fractured and fissured the rocks are. It is also assumed that vertical rock fractures are dominant in the study area and are exposed on the surface as linear features, and that groundwater flow tends to concentrate in zones of highly fractured rocks and moves down gradient along the most fractured zones. This implies that a cavern passage changes its development direction only if another direction offers a more favourable pathway (i.e., more fractured and shorter distance to the resurgence point). These assumptions form a set of rules, which can be used to predict the underground conduits on the basis of a lineament density map. Implementation of the method is given below.

One of the basic data for the analysis is a 1:50,000 scale geologic map, which was made on the basis of an extensive field survey using a grid of $500 \times 500 \mathrm{~m}$ over the study area (Hop 1996). Field measurements of rock dip azimuths were interpolated throughout the study area by the Thiessen polygon method. Because of such a dense measurement grid, the interpretation error is considered to be insignificant although the Thiessen method is generally limited to measurements that vary in a continuous manner across a region. The resulting polygons of rock dip azimuths and faults drawn on the geological map were digitised to create two vector sets. The polygon map with rock dip azimuths was rasterised on a $300 \times 300 \mathrm{~m}$ cell-sized grid. Bodin and Razack (1999) showed how image-processing techniques can be used to analyse the geometry of fracture networks. Following a similar methodology a set of lineaments was extracted from a $30 \mathrm{~m}$ resolution Landsat 7 ETM satellite image using a digital automatic processing scheme (Hung et al. 2002). The lineaments were also corrected by stereoscopic visualization of airborne photos of scale 1:33,000 to eliminate non-geologic linear features (e.g., roads, irrigation channels, etc.) from the satellite image. The fault scheme, the map of rock dipp azimuth, and the lineament scheme were verified in the field with 23 ground control points. Finally, a lineament-length density grid map with a resolution of $300 \times 300 \mathrm{~m}$ was created with GIS tools. The 
Fig. 10 Map with lineament-length density and predicted underground flow paths; the minimum, mean, and maximum values of lineament-length density are respectively $0,0.3$, and $1.29 \mathrm{~km} / \mathrm{km}^{2}$

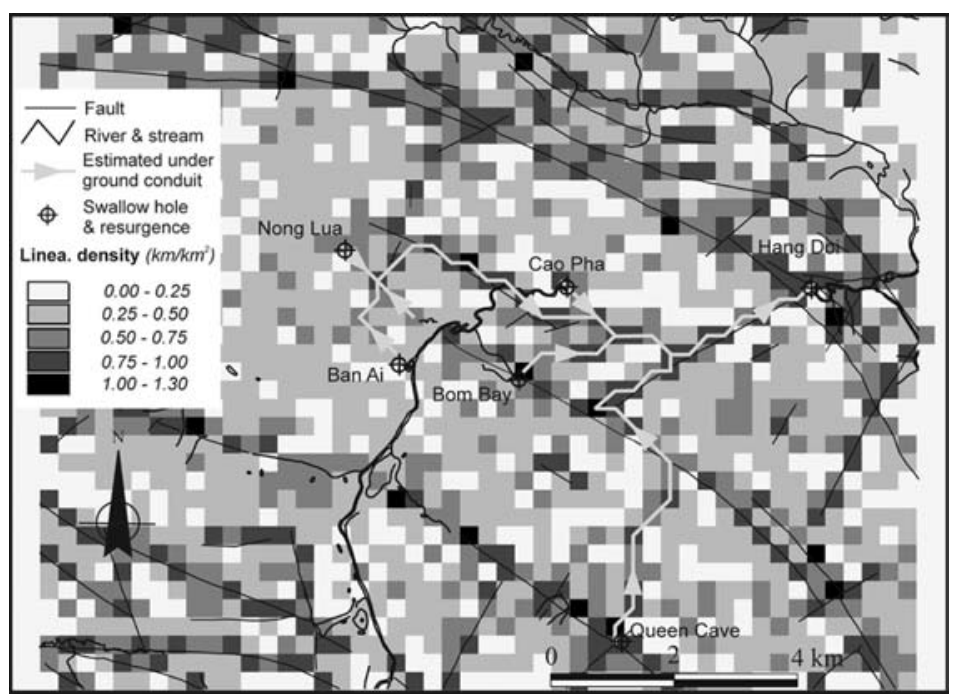

lineament-length density $\mathrm{D}_{\mathrm{L}}$ in this map was calculated as

$D_{L}=\frac{1}{A} \sum_{\mathrm{i}=1}^{i=n} L_{i}\left(\mathrm{~m} / \mathrm{m}^{2}\right)$

where $L_{i}$ is the length of the $i$ th lineament recorded in cell area $A$.

A good agreement between the areas of high $D_{L}$ values and the occurrence of the geological faults can be observed in the lineament density map (Fig. 10). A more detailed analysis reveals that in a $300 \mathrm{~m}$ buffer zone along the faults, $82 \%$ of the cells have a lineament-length density higher than $0.4 \mathrm{~km} / \mathrm{km}^{2}$, while outside the fault buffer zone $90 \%$ of the cells have a density smaller than $0.4 \mathrm{~km} / \mathrm{km}^{2}$. Therefore, it can be concluded that zones of high-density of lineaments are very fractured, indicating the locations where conduits are most likely to occur.

Hence, with the resulting density map routes can be delineated, which connect cells of high lineament density, from a source point to a destination point. A routine was written for automatic delineation of these routes. The routine works on the basis of a $3 \times 3$ cell window (Fig. 11) in which the centre cell is considered as the current routing position. The window is subsequently moved to one of the eight surrounding cells, which has the highest weighting value of $D_{L}$ (the weighting factor $F$ will be explained hereafter), excluding those masked as no-routing cells and the cell from the preceding routing step. No-routing cells are read from a grid, which is used to mask areas that cannot be entered, as for instance areas with non-limestone rocks. If two or more cells have the same lineament-length density, the window is moved to the cell that is closest to the destination. In each movement, the routine records the location of the cell the window passes through, the cell's $D_{L}$ value, and the movement distance. The routine terminates when (i) the window reaches the destination; (ii) the window is blocked in all directions by no-routing cells and/or cells having a value below a threshold; and (iii) looped processing (i.e. returning back to its previous route) is encountered.
The threshold value is related to the lineament density, i.e. below a certain lineament density the cavern passages cannot develop. The threshold is empirically selected and is mostly taken as the average $D_{L}$ for cells outside the fault buffer zone.

In the assumption stated earlier, lineament-length density is an indicator for the degree of rock fracturing, which is a prerequisite for development of cavernous passages. However, as shown in the cave structure analysis, not only the rock fractures but also the geological structure influences the cavernous conduit development. Therefore, information on the geological structure must be taken into account during the routing, necessary, for example, in tracing a cave passage that develops along a bedding plane. Thus, structural direction, i.e. the rock-dipping azimuth, is necessary to enforce the routing and to ensure the consistency of the cave development with the local structural continuity. A change in direction of the cave development is conceptualised as the result of a prominent change in rock fracturing, i.e. the density $D_{L}$. On the other hand, the density $D_{L}$ itself does not include any information on the orientation of the mapped lineaments, i.e. the fracture orientation. Spatial uncertainty associated with a mapped lineament makes it less meaningful to refer to the strike of an individual lineament. Instead, a reference to a group of lineaments should be made. A rose diagram showing the directional frequency of the lineaments was considered as a statistical means representing the anisotropy of the fractured environment, as well as the cave development tendency on a regional scale. Therefore, the fracture anisotropy should be included to amend undesired movements of the routing window. In this study, the influence of the local geological structure and the regional fracture development tendency on the cave development was assumed to be equal and included in a weighting factor $F$. This factor rates the possibility of cave development by way of a regional tendency coefficient $f_{\delta}$, and a local geological structural orientation coefficient $f_{\beta}$, i.e.

$F=\frac{1}{2}\left(f_{\delta}+f_{\beta}\right)$ 

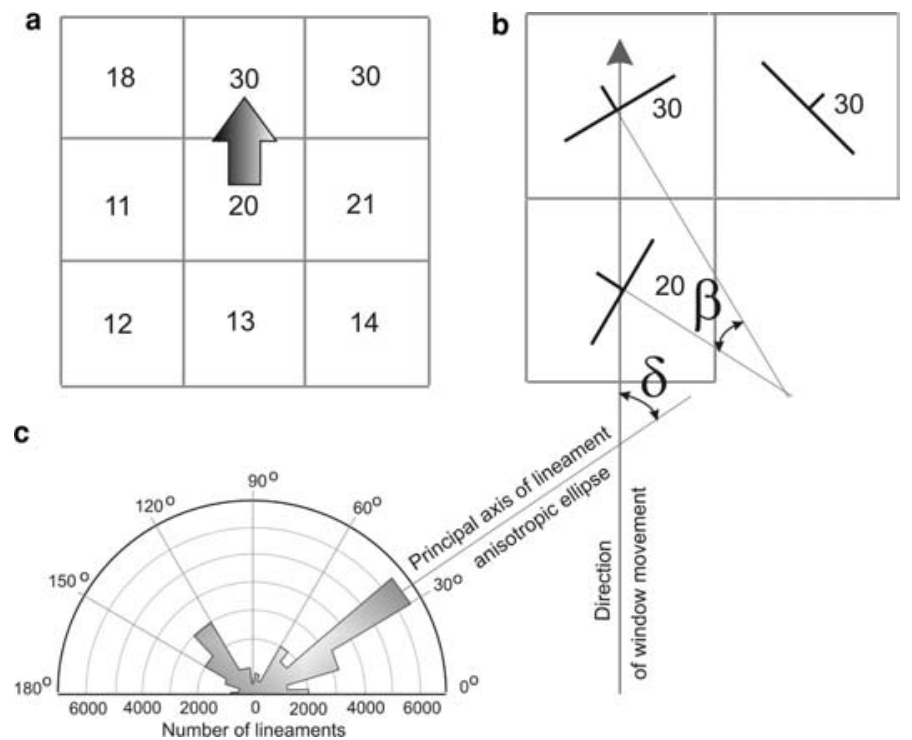

Fig. 11 Explanation of the tracking method for underground flow paths: (a) local window with cell values denoting the lineament density $D_{L}$, the arrow shows the direction in which the window is moved; (b) close-up of the local window in which the lower cell is the center cell of the local window. The cell values denote the product of the weighting factor and the lineament density $F D_{L} . \delta$ is the angle

Coefficient $f_{\delta}$ depends upon the direction in which the window tends to move and the regional lineament distribution, shown by the rose diagram in Fig. 11c; the coefficient is calculated as

$f_{\delta}=\frac{1}{\cos ^{2} \delta+a \sin ^{2} \delta}$

where $\delta$ is the angle between the direction in which the window tends to move and the orientation of the major axis of the lineament distribution, hence $0^{\circ} \leq \delta \leq 90^{\circ}$; the angle can be determined on the basis of the lineament rose diagram, as illustrated in Fig. 11b. Coefficient $a$ is defined as the ratio between the number of lineaments in the major direction and in the second major direction. This coefficient is constant and can be calculated based on the lineament rose diagram as $65 / 30 \approx 2.2$.

Coefficient $f_{\beta}$ depends upon angle $\beta$, which is the angle between rock dipping azimuth of the present location and the cell where the window tends to move, as shown in Fig. $11 \mathrm{~b} ; f_{\beta}$ were taken equal to 1 when $\beta \leq \varepsilon$ because cave development along the direction of the strata strike is very likely, or when $|\beta-90| \leq \varepsilon$, because cave development in the direction of the strata dipping is also very likely; otherwise $f_{\beta}$ is zero. Angle $\varepsilon$ is taken as $15^{\circ}$ and is considered as the uncertainty associated with fieldwork measurements or data processing such as digitisation.

Note that $0<f_{\delta} \leq 1$ and $f_{\beta}=[0,1]$ such that $0<F \leq 1$. During the routing the coefficient $F$ weights the density $D_{L}$, i.e. the value $F D_{L}$ decides to which cell the window moves, as shown in Fig. 11b. In the example presented in the Fig. 11, for the northern cell, $\delta=45^{\circ}$ and $\beta=15^{\circ}$, hence $f_{\delta}=0.63$ and $f_{\beta}=1$, it follows that the weighting is $0.5(0.63+1)$

between the direction in which the window tends to move and the orientation of the major axis of the regional lineament distribution. $\beta$ is the angle between the rock-dipping azimuth of the center cell and of the cell where the window tends to move to. The window moves to the north in conformity with the $F D_{L}$ value; and (c) the rose diagram exhibits the anisotropy of lineament development in the study area

$30 \approx 24.4$; while for the NE cell, $\delta=0^{\circ}$ and $\beta=180^{\circ}$, such that $f_{\delta}=1$ and $f_{\beta}=0$, and the weighting becomes $0.5(1+0)$ $30=15$; consequently, the window will move to the north.

Applying the above methodology to the study area resulted in routes of highest fracture densities and shortest length, which connect the swallow holes and the resurgence. These are the most plausible pathways of the underground conduits. Figure 10 shows the resulting pathways of the underground conduits estimated with the lineamentfault-cave analysis. It was noted that all routed underground conduits converge to the same resurgence point and exhibit a branchwork cave development pattern. It was also observed that many routed segments coincide with the direction of the faults. The tributaries of the routed underground conduits re-assert the conclusions from geological studies (Hop 1996; Xuyen 1997) that the NE-SW and sub-longitudinal striking faults are much more significant compared to the NW-SE striking faults. In addition, this analysis also indicated the likeliness of an underground passage from the Ban Ai swallow hole to the Nong Lua doline and an additional conduit that further connects to the resurgence at Hang Doi.

\section{Conclusions}

A tracer test is one of the tools giving the clearest proof of a connection between two points of interest in a karst system, however it is not practically applicable in all circumstances. Other techniques based on discharge data, geostructural, caving and remote sensing data offer alternative methods for the study of karst systems and can be integrated with traditional tracer studies. The integrative approach, followed 
in this study, clearly yielded new knowledge on the investigated karst system beyond the level of what could be obtained by the tracer experiments alone.

In the study area the existence of the following system of three main underground conduits between swallow holes and a resurgence in the Nam La catchment were investigated: (i) from the Ban Ai swallow hole to the Nong Lua doline and further to the resurgence at Hang Doi; (ii) from the Cao Pha swallow hole to the resurgence at Hang Doi; and (iii) from the Bom Bay swallow hole to the Hang Doi resurgence.

Streamflow cross-correlation analysis showed that there is a high correlation between the discharge of the Nam $\mathrm{La}$ River, before it disappears in the swallow holes, and the discharge at the resurgence. The maximum cross-correlation occurs at about $13 \mathrm{~h}$ of time lag, while the maximum time lag is 63 days. This shows on one hand that the dynamic response of the karst system is relatively quick while on the other hand the internal storage of the conduit system must be large. These conclusions are also supported by the analysis of the cross-amplitude function, which showed that low-flow components have a relatively direct response in the discharge of the resurgence, while high flow components are attenuated by the system. As an explanation for this attenuation the storage in conduits, fractures, fissures and dolines was proposed.

A performed tracer test proved that a groundwater flow connection exists between Cao Pha and Bom Bay swallow holes and the resurgence. The low concentration of the measured tracer at the resurgence, the low recovery rate of the tracer and the relatively long time $(20 \mathrm{~h})$ of the first moment of arrival of the tracer points again to a large storage and a mass transfer through the karst system which is much slower than the dynamic response.

Analysis of the discharge time series shows that the discharge of the resurgence were limited to about $25 \mathrm{~m}^{3} / \mathrm{s}$. For peak flows it was observed that the inflow to the swallow holes were bigger than outflow at the resurgence. Water balance calculations showed that the difference in discharge can be stored in a nearby doline. The time of ponding in this doline were recorded to coincide with the time of peak of the discharge at the resurgence, while flooding traces in the doline correspond to the estimated water level in the doline. Additionally, cave mapping shows possible inflow and outflow conduits in the doline shaft. The functioning of the flow paths depends on the discharge regime. If the Nam La streamflow is less than $25 \mathrm{~m}^{3} / \mathrm{s}$, the Ban Ai-Nong Lua - Hang Doi underground conduit is the major drainage path, while the Cao Pha - Hang Doi and the Bom Bay Hang Doi are in that case of minor importance. However, if the streamflow exceeds $25 \mathrm{~m}^{3} / \mathrm{s}$, then the latter flow paths become more important. The Nong Lua dolines act therefore as a temporal storage of the Nam La streamflow during extensive rainy periods.

Analysis of the cave mapping and geostructural data show that the directions of the caves coincide with the two major directions of fault and shear zones and that caves reorient themselves at a certain level according to a changing drainage level and fault direction. It is also shown that faults and caves are systematically aligned in the areas with a high density of lineaments. It was therefore concluded that the lineaments derived from remote sensing can be used to indicate the existence of conduits.

A methodology was elaborated which determines flow paths from swallow hole to resurgence following the highest density lineament path. Structural information and the directional frequency of the lineaments, derived from the rose diagrams, is also included in the simulation of the tracked path. Applying the methodology resulted in plausible pathways for the three conduit systems, showing a branchwork cave development pattern converging to the Hang Doi resurgence point. The results of the application of the lineament method are fully in line with the other assessments of the karstic system and re-assert the conclusions from geological studies in which the importance of the NESW faults were suggested. The methodology is therefore an effective tool for flow path screening and can also be used as a low cost reconnaissance tool prior to subsequent expensive tracer tests or geophysics survey campaigns.

This research increased the understanding of the Nam La karst system and it has therefore an important societal value in possible flood mitigation and use of karst water resources. Finally, this work shows that a multi-thematic approach is clearly advantageous in improving and understanding the insight of the hydrological functioning of a complex karst system.

Acknowledgements This work has been carried out within the project A3210 "Rural development in the mountain karst area of NW Vietnam by sustainable water and land management and social learning: its conditions and facilitation (VIBEKAP)" funded by the Flemish University Council (VLIR). The authors are grateful to all VIBEKAP's participants for their contributions. Special thanks is paid to the former Project Coordinator, Dr. Koen Van Keer for his warm encouragement and support to this study.

\section{Appendix}

The time series cross analysis used in this study utilizes the cross-correlation function and cross-amplitude function. An overview of these functions is presented here to facilitate the comprehension of the study results. More detailed explanations and complete theoretical backgrounds can be found in Jenkin and Watts (1968), Yevjevich (1972), Oppenhiem and Schafer (1975), Box and Jenkins (1976), and others.

\section{Cross-correlation function (CCF)}

Let there be two discretised chronological series: the input, $x_{i}\left(x_{1}, x_{2}, \ldots, x_{n}\right)$, is the cause of the output, $y_{i}\left(y_{1}, y_{2}, \ldots, y_{n}\right)$, where $n$ is the total number of data pairs. The autocorrelation function $(\mathrm{ACF}), r_{x}(k)$, quantifies the linear dependency of successive values of the time series $x_{i}$ and is defined as

$r_{x}(k)=\frac{C_{x}(k)}{C_{x}(0)}$ 
where $k$ is the time lag ( $k=0$ to $m$ ), with $m$ the cutting point, which determines the length of the analysis; $C_{x}(k)$ is the autocovariance function given by

$C_{x}(k)=\frac{1}{n} \sum_{i=1}^{n-k}\left(x_{i}-\bar{x}\right)\left(x_{i+k}-\bar{x}\right)$

with $\bar{x}$ the mean of the series.

The correlogram $C(k)$ outlines the memory of the system. If an event has a long-term influence on the time series, the autocorrelation function decreases slowly with increasing time lag.

The cross-correlation function (CCF) represents the impulse response of the system under investigation when the input series is considered to be a white noise, and is described by following expressions

$r_{+k}=r_{x y}(k)=\frac{C_{x y}(k)}{\sigma_{x} \sigma_{y}}$

$r_{-k}=r_{y x}(k)=\frac{C_{y x}(k)}{\sigma_{x} \sigma_{y}}[-10 p t]$

where $C_{x y}$ and $C_{y x}$ are cross-covariance functions, and $\sigma_{x}$ and $\sigma_{y}$ standard deviation of the series, given by

$C_{x y}(k)=\frac{1}{n} \sum_{t=1}^{n-k}\left(x_{t}-\bar{x}\right)\left(y_{t+k}-\bar{y}\right)$

$C_{y x}(k)=\frac{1}{n} \sum_{t=1}^{n-k}\left(y_{t}-\bar{y}\right)\left(x_{t+k}-\bar{x}\right)$

$\sigma_{x}=\sqrt{\frac{1}{n} \sum_{t=1}^{n}\left(x_{t}-\bar{x}\right)^{2}}$

$\sigma_{y}=\sqrt{\frac{1}{n} \sum_{t=1}^{n}\left(y_{t}-\bar{y}\right)^{2}}$

and $\bar{y}$ is the mean of the series $y_{i}$.

Note that the cross-correlation function is not symmetrical, $r_{x y}(k) \neq r_{y x}(k)$. If $r_{x y}(k)>0$ for $k>0$, the input series $x_{i}$ influences the output series $y_{i}$, while if $r_{x y}(k)>0$ for $k<0$, the output influences the input. The delay time, defined as the time lag between $k=0$ and the maximum of $r_{x y}(k)$, gives an estimation of the peak impulse response time of the system.

\section{Cross-amplitude function (CAF)}

Spectrum analysis is concerned with the exploration of cyclical patterns. The purpose of the analysis is to decompose a complex time series with cyclical components into a few underlying sinusoidal functions of particular wavelength or frequency, $f$, the number of cycles per unit time.
Thus, by identifying the underlying cyclical components, the phenomenon of interest is characterised. Changing from a time mode to a frequency mode is performed by way of a Fast Fourier Transform (FFT).

The spectral density function, $S_{x}(f)$, of the time series $x_{i}$, corresponding to the discrete-time Fourier transform of the autocorrelation function, is defined as

$S_{x}(f)=\frac{1}{2}\left[1+\sum_{k=1}^{m} D(k) r_{x}(k) \cos (2 \pi f k)\right]$

where $D(k)$ is a filter necessary to overcome the problem of "chaotic" spikes occasionally occurring in the time series. The most frequently used filter in the analysis of the hydrological series is the Turkey filter, which is expressed as

$D(k)=\frac{1}{2}\left(1+\cos \frac{\pi k}{m}\right)$

The cross-spectral density function, $S_{x y}(f)$, gives the frequency mode of the cross-correlation function and is expressed as a complex number

$S_{x y}(f)=h_{x y}(f)-i \lambda_{x y}(f)$

where the real part is the co-spectrum

$$
\begin{aligned}
h_{x y}(f)= & 2\left[r_{x y}(0)+\sum_{1}^{m}\left(r_{x y}(k)+r_{y x}(k)\right)\right. \\
& \times D(k) \cos (2 \pi f k)]
\end{aligned}
$$

and the imaginary part is the quadrature spectrum

$$
\begin{aligned}
\lambda_{x y}(f)= & 2\left[r_{x y}(0)+\sum_{1}^{m}\left(r_{x y}(k)+r_{y x}(k)\right)\right. \\
& \times D(k) \sin (2 \pi f k)]
\end{aligned}
$$

The square root of the sum of the squared co-spectrum and quadrature spectrum is called the cross-amplitude function (CAF) and is expressed as

$\alpha_{x y}(f)=\sqrt{h_{x y}^{2}(f)+\lambda_{x y}^{2}(f)}$

The cross-amplitude can be interpreted as a measure of covariance between the respective frequency components in the two series, and identifies the way in which the input signal has been modified by the system. The CAF can be associated with the duration of the impulse response function and indicates the filtering of the periodic components of the input series Padilla and Pulido-Bosch (1995). 


\section{References}

Bodin J, Razack M (1999) L'analyse d'images appliquée au traitement automatique de champs de fractures. Propriétés géométriques et lois d'échelles. Bull Soc Géol France 170(4):579-593

Bonacci O (2001) Analysis of the maximum discharge of karst springs. Hydrogeol J 9:328-338

Box GEP, Jenkins GM (1976) Time series analysis forecasting and control. Holden Day, San Francisco, CA, 575 pp

Davis WM (1930) Origin of limestone caverns. Geol Soc Am Bull 41:475-628

Dinh NQ (2001) Cave database development, Spatial analysis and 3D visualization with GIS, Case study in Son La (Vietnam). Master dissertation, Free University Brussels, $114 \mathrm{pp}$

Dreybrodt W (1992) Dynamics of karstification: a model applied to hydraulic structures in karst terranes. Appl Hydrogeol $1(3): 20-32$

Edet AE, Okereke CS, Teme SC, Esu EO (1998) Application of remote-sensing data to groundwater exploration: a case study of the Cross River State, southeastern Nigeria. Hydrogeol J 6:394-404

Eisenlohr L, Király L, Bouzelboudjen M, Rossier Y (1997) Numerical simulation as a toll for checking the interpretation of karst spring hydrographs. J Hydrol 193:306-315

Estrela T, Sahuquillo A (1997) Modelling the response of a karstic spring at Arteta Aquifer in Spain. Ground Water 35(1):1824

Felton GK, Currens JC (1994) Peak flow rate and recession-curve characteristics of a karst spring in the Inner Bluegrass, central Kentucky. J Hydrol 162:99-118

Ford DC, Williams PW (1989) Karst geomorphology and hydrology. Unwin Hyman, London, 601 pp

Ford DC (1999) Perspectives in karst hydrogeology and cavern genesis. In: Palmer AN, Palmer MV, Sasowsky ID (eds) Proceedings of the Karst Modeling Symposium, Charlottesville, Virginia, February 24-27, 1999, vol 5. Karst Water Institute, Spec Publ, pp 17-29

Ford DC, Ewers RO (1978) The development of limestone cave systems in the dimensions of length and breadth. Can J Earth Sci 15:1783-1798

Hop ND (1996) Report on geological mapping scaled 1:50000, Thuan Chau Area. Research Institute of Geology and Mineral Resources of Vietnam (in Vietnamese), Hanoi, $178 \mathrm{pp}$

Hung LQ (2001) Remote sensing based hydrogeological analysis in Suoi Muoi Catchment-Vietnam. Masters dissertation, Vrije Universiteit Brussel, 88 pp

Hung LQ, Dinh NQ, Batelaan O, Tam VT, Lagrou D (2002) Remote sensing and GIS-based analysis of cave development in the Suoimuoi Catchment (Son La - NW Vietnam). J Cave Karst Stud 64(1):23-33

Jenkins GM, Watts DG (1968) Spectral analysis and its applications. Holden Day, San Francisco, CA, 525 pp

Jian WB, Yao H, Wen XH, Chen BR (1998) A nonelinear time series model for spring flow: an example from Shanxi Province, China. Groundwater 36(1):147-150

Kastning EH (1999) The surface-subsurface interface and the influence of geologic structure in karst. In: Palmer AN, Palmer MV, Sasowsky ID (eds) Proceedings of the Karst Modeling Symposium, Charlottesville, Virginia, February 24-27, 1999, vol 5. Karst Water Institute, Spec Publ, pp 43-47

Király L, Perrochet P, Rossier Y (1995) Effect of the epikarst on the hydrograph of karst springs; a numerical approach. Bul Centre d' Hydrogéol Neuchâtel 14:1-22

Knez M (1997) Speleogenesis of phreatic channels in bedding-planes in the frame of karst aquifer (Skocjanske jama Caves, Slovenia). Proceedings of the 12th International Congress of Speleology, vol 11, La Chaux-de-Fonds, Switzerland, pp 279-282

Kresic N, Papic P, Golubovic R (1992) Elements of groundwater protection in a karst environment. Environ Geol Water Sci 20(3):157-164
Lachassagne P, Wyns R, Bérard P, Bruel T, Chéry L, Coutand T, Desprats JF, Strat PL (2001) Exploitation of high-yield in hard-rock aquifers: downscaling methodology combining GIS and multicriteria analysis to delineate field prospecting zones. Ground Water 39(4):568-581

Larocque M, Banton O, Ackerer P, Razack M (1999) Determining karst transmissivities with inverse modeling and an equivalent porous media. Ground Water 37(6):897-903

Larocque M, Mangin A, Razack M, Banton O (1998) Contribution of correlation and spectral analyses to the regional study of a large karst aquifer (Charente, France). J Hydrol 205:217-231

Long AJ, Derickson RG (1999) Linear systems analysis in karst aquifer. J Hydrol 219:206-217

Mabee SB, Hardcastle KC, Wise DU (1994) A method of collecting and analyzing lineaments for regional-scale fractured-bedrock aquifer studies. Ground Water 32(6):884-894

Magowe M, Carr JR (1999) Relationship between lineaments and ground water occurrence in western Botswana. Ground Water 37(2):282-286

Mangin A (1984) Pour une meilleure connaissance des systèmes hydrologiques à partir des analyses corrélatoire et spectrale. J Hydrol 67:25-43

November J (1999) Karstgeologisch onderzoek in het gebied van Son La en Thuan Chau (NW-Vietnam). K.U. Leuven, Lic.-thesis (in Dutch), $135 \mathrm{pp}$

Oppenhiem AV, Schafer RW (1975) Digital signal processing. Prentice Hall, NJ, 585 pp

Padilla A, Pulido-Bosch A (1995) Study of hydrographs of karstic aquifers by means of correlation and cross-spectral analysis. J Hydrol 168:73-89

Palmer AN (1991) Origin and morphology of limestone caves. Geol Soc Am Bull 103:1-21

Sander P, Minor TB, Chesley MM (1997) Ground-water exploration based on lineament analysis and reproducibility tests. Ground Water 35(5):888-894

Sasowsky ID (1999) Structural Effects on carbonate aquifers. In: Palmer AN, Palmer MV, Sasowsky ID (eds) Proceedings of the Karst Modeling Symposium, Charlottesville, Virginia, February 24-27, 1999, vol 5. Karst Water Institute, Spec Publ, pp 38-42

Smart PL, Hobbs SL (1986) Characterization of carbonate aquifers: a conceptual base. Proceedings of the Environmental Problems in Karst Terranes and Their Solutions, Conference. Bowling Green, KY, pp 1-14

Spolia SK, Chander S (1973) Modeling of surface runoff system by ARMA model. J Hydrol 22:317-332

Tam VT, Vu TMN, Batelaan O (2001) Hydrogeological characteristics of a karst mountainous catchment in the northwest of Vietnam. Acta Geol Sinica (English Edition) 75(3):260 268

Tri TV, Ngoc D (1986) Report on the tectonic map of scale 1:1,000,000 of Vietnam. Research Institute of Geology and Mineral Resources (in Vietnamese), 134 pp

Turcotte R, Fortin JP, Rousseau AN, Massicotte S, Villeneuve JP (2001) Determination of the drainage structure of a watershed using a digital elevation model and a digital river and lake network. J Hydrol 240(3-4): 225-242

White WB (1969) Conceptual models of carbonate aquifers. Ground Water 7(3):15-21

White WB (1999) Conceptual models for karstic aquifers. In: Palmer AN, Palmer MV, Sasowsky ID (eds) Proceedings of the Karst Modeling Symposium, Charlottesville, Virginia, February 24-27, 1999, vol 5. Karst Water Institute, Spec Publ, pp 11-16

Xuyen CS (1997) Groundwater in the northwest Vietnam and groundwater supply capacity for centralized economic areas in the region. National Conference on Groundwater Resources (in Vietnamese), Research Institute of Geology and Mineral Resources, Hanoi, November 1997, pp 35-39

Yevjevich V (1972) Stochastic processes in hydrology. Water Resources Publications, Fort Collins, CO, 302 pp 